\title{
Linking Affect and Creative Performance at Work Context
}

\author{
Zhang Da Long, Zhang Jian* and Ye Lan \\ Donlinks School of Economics and Management, University of Science and Technology, China
}

Submission: October 30, 2017; Published: November 30, 2017

*Corresponding author: Zhang Jian, Donlinks School of Economics and Management, University of Science and Technology, China, Email: zhangj67@manage.ustb.edu.cn

\begin{abstract}
The influence of affect on creativity has been an area of active debate focused on whether positive or negative affect leads to better creative performance. This study summarizes several perspectives in the relationship between employee affect and creative performance at workplace, and proposes a new affective classification. This affective classification posits that affect with respect to need satisfaction is positively related to creativity performance if employees' needs are satisfied, and affect under need thwarting is negatively related to creativity performance if employees' needs are impeded. We discuss the implications of these findings for creativity theory, research, and management practice.
\end{abstract}

Keywords: Affect, Creative Performance; Basic Psychological Needs; Self-determination Theory

\section{Introduction}

Many organizations rely on employee creativity for competitive advantage, adaptation, and survival. Thus, it is not surprising that understanding creativity in organizations is a high priority for research in organizational behavior. Given the dominant role of creativity in the workplace, affect represents one of the most widely studied and least disputed predictors of creativity performance [1]. However, there is no consensus in the research on the relationship between affect and creative performance. For example, some studies show that a positive emotional state favors creativity [2], whereas others show that a negative emotional state leads to more creativity than positive and neutral emotional states [3]. The divergence between affect and work creativity has caused researchers to examine the relationship that exists between the two, to question the type of affect that improves creativity and to search for more complex patterns, such as the curvilinear effects of affective intensity, affective ambivalence, or affective liability, to solve the problem [4].

Addressing this debate within the organizational domain, Weiss and Cropanzano 1996 note that as the wide variety of possible human affective experiences not only have valence but also have intensity [5], we should consider affective intensity when we discussing the influence of affect on creativity. There might be a U-shaped relationship whereby intense negative or positive affect contributes to creativity and whereby moderate levels of affect are insufficient to stimulate the needed cognitive resources [6]. Alternatively, according to the early theoretical work of Yerkes and Dodson 1908, the affect-creativity relationship could follow an inverted U-shaped function.

The progress of the research seems to inspire us that there is no longer a "one size fits all" way to measure workrelated affect, such as using general attitudinal measures or job satisfaction [7]. The mood-as-input model suggests that moods provide people with information [8] and that the significance and consequences of the information provided by one's current mood state depend on the context. Thus, we can classify affect according to environment. Self-determination theory (SDT) is a human behavior motivation theory that proposes the contextual variable of autonomy support facilitates basic psychological needs and the integration of regulations and values. The SDT model distinguishes the environment into an informational context and a controlling context [9] and further suggests that there are no good or bad affect because all affective experiences provide organismically valuable guidance [10].

Based on self-determination theory, we put forward the concept of affect under need satisfaction and need thwarting and explore the content of this affective classification according to affective valence and intensity. Affect under need satisfaction will develop when the individual's underlying autonomous supportive environment and needs are satisfied, which in turn is beneficial to the individual's work behavior and creative performance. Affect under need thwarting will develop when the 
individuals underlying controlling environment and needs are hindered, which is harmful to the individual's work behavior and creative performance. Developing this affective classification holds the potential of an improved psychological understanding of affect and may show pathways to facilitate creativity.

\section{Conclusion}

First, we propose a new affective classification affect under need satisfaction and need thwarting. The results indicate that affect under need satisfaction included moderate levels of excitement, enthusiasm, pride, interest, attention, inspiration, determination, strength, and energy. The affect under needs thwarting includes slight levels of irritability, alertness, strength, energy, anxiety, anger, distress, attention, and determination, and low levels of nervousness and free. This classification is an important step in affect and creativity research. Second, two types of affect can enrich the theoretical research, which then provides new ideas for future research regarding organizational events and employee affect. Third, the present study improves the leaders and managements' understanding of employees' psychological needs, which can facilitate the organization in creating a more productive organizational environment by producing affect under need satisfaction.

\section{Acknowledgement}

Thanks for the support of grants from Ministry of Education of Humanities and Social Science project (grant number 15YJA630099) and from National Natural Science Foundation of China (NSFC) project (grants number 71771022).

\section{Conflict of Interest}

No conflict of interest exists in the submission of this manuscript, and manuscript is approved by all authors for publication.

\section{References}

1. Mumford MD (2003) Where have we been, where are we going? Taking stock in creativity research. Creativity Research Journal 15(23): 107-120.

2. Isen AM (1999) On the relationship between affect and creative problem solving. Affect creative experience and psychological adjustment 3: 3-17.

3. Hirt ER, Melton RJ, McDonald HE, Harackiewicz JM (1996) Processing goals task interest, and the mood-performance relationship: A meditational analysis. Journal of personality and social psychology 71(2): 245-261.

4. Amabile TM, Barsade SG, Mueller JS, Staw BM (2005) Affect and creativity at work. Administrative science quarterly 50(3): 367-403.

5. Weiss HM, Cropanzano R (1996) Affective events theory: A theoretical discussion of the structure causes and consequences of affective experiences at work. Research in organizational behavior (18): 1-74.

6. Amabile TM (1988) A model of creativity and innovation in organizations. Research in Organizational Behavior 10: 123-167.

7. Barsade SG, Gibson DE (2007) Why does affect matter in organizations? Academy of Management Perspectives 21(1): 36-59.

8. Clore GL, Schwarz N, Conway M (1994) Affective causes and consequences of social information processing. Handbook of social cognition 1: 323-417.

9. Deci EL, Ryan RM (1985) Intrinsic motivation and self-determination in human behavior. Plenum, New York.

10. Deci EL, Ryan RM (2000) The" what" and" why" of goal pursuits: Human needs and the self-determination of behavior. Psychological inquiry 11(4): 227-268.

Your next submission with Juniper Publishers will reach you the below assets

- Quality Editorial service

- Swift Peer Review

- Reprints availability

- E-prints Service

- Manuscript Podcast for convenient understanding

- Global attainment for your research

- Manuscript accessibility in different formats

( Pdf, E-pub, Full Text, Audio)

- Unceasing customer service

Track the below URL for one-step submission https://juniperpublishers.com/online-submission.php 